\title{
POLITICS AND UTOPIA
}

New York, N. Y. SIR: Those of us who are sometimes accused of "surrender to power politics" and of having "lost the prophetic note" in our approach to the nation's foreign policy might well carry around with us a copy of your January, 1959 issue. We could show our critics the essay, "Politics and Utopia" by Thomas Molnar and' say, "If you think we have gone overboard in recognizing the place of power in international relations, read Mr. Molnarl Here is a man who, in his anxiety to refute idealists and sentimentalists, sees no place for anything except power and is prepared to use power, literally, without limits." This is about the only value I can see in Mr. Molnar's essay.

For one thing, Mr. Molnar, as your editorial gently states, is beating an almost-dead horse. Who, today, has the kind of blind faith in "the goodness of man and the noble flow of history" which Mr. Molnar attributes to "utopians" and "reformists"? I know many pacifists and near-pacifists but few of them fit Mr. Molnar's description. More important, I doubt if many leading statesmen of the Western world, however much they may appreciate the necessity of power in international affairs, have the contempt for everything except power which Mr. Molnar seems to have.

Unity and security are, respectively, the domestic and extemal aims of national governments, says $\mathrm{Mr}$. Molnar. And "the instruments of security range from diplomatic skill to the use of lethal weapons." If this is a full statement of the national aim and of the available instruments, why are we wasting time and substance with programs of economic aid, cultural exchange, and Information Services, to mention only a few of the instruments government uses which cannot be subsumed under either diplomacy or lethal weapons?

One must, of course, agree that unity (welfare should be added) and security are the main purposes for which national governments exist. But Mr. Molnar needs both a broader definition of security and a much more comprehensive list of instruments through which the security may be achieved. It may be added that in the world of Mr. Molnar, where we are advised not to give an inch in Asia, North Africa, or anywhere else, we might also just as well dispense with our diplomats; it will be sufficient to let the military leaders pile up the lethal weapons, stand on top of them, and shout defiance.

It is true, as Mr. Molnar says, "that the reformist or utopian usually has contempt for the structure of life, its given situations and hard data." But the kind of "realism" here recommended takes into account only the situations and hard data which fit the prescription of undiluted power. Consider the Chinese dictators. It is a hard fact that they want hegemony in the Pacific and will not be turned from their purpose by kind words or concessions. It is also a hard fact that they are non-white Orientals who have suffered denigration at the hands of white Western nations and who are now motivated, not only by power impulses and Marxist ambitions, but also by normal human resentments. It is at this point that we could do at least something to relar the tension-but not by a display of power.

Similarly, the Russian dictators have purposes which will not be affected by courtesies and conces. sions, but they are also genuinely afraid of the West and also suffer from a feeling of inferiority. To try to meet all hard facts with hard steel is to be as unrealistic as those whom the would-be realists hold up to scorn. In human relations-and international relations are still directed by human beings-unyielding "firmness" may be as mistaken as Emerson's "mush of concession."

May I ald the opinion that, in your editorial "Varieties of Utopianism," your way of turning the tables on Mr. Molnar by accusing him, in effect, of unconscious forms of utopianism, is questionable. Making power the answer to our problems, isolationism, and dreams of Western hegemony are indeed unrealistic, but they have nothing in common with utopianism, which is the belief that, by certain actions, we can arrive at a state of ideal perfection. Utopianism has a moral goal. But in mere unity and security, as Mr. Molnar seems to interpret them, and in the instruments to which he thinks governments should limit themselves, it is hard to detect anything that one could call a moral quality.

HERMAN F. REISSIG United Church of Christ, Council for Christian Social Action 